American Journal of Agricultural and Biological Sciences 2 (1): 15-22, 2007

ISSN 1557-4989

(C) 2007 Science Publications

\title{
The Influence of Social Capital on Adoption of Rural Development Programs by Farmers in the Caspian Sea Region of Iran
}

\author{
A. Ahmadi Firouzjaie, H. Sadighi and M. A. Mohammadi \\ College of Agriculture, Tarbiat Modares University, Tehran, Iran \\ College of Agriculture, Tarbiat Modares University, P.O.Box 336-14115, Tehran, Iran; \\ University of Social Welfare \& Rehabilitation Sciences, Tehran Iran
}

\begin{abstract}
The main purpose of this study was to measure social capital (consisting of structural and cognitive) of mainly rice producing farmers in the Caspian See region of Iran. The secondary purpose was to determine the influence of farmers' social capital on adoption of Rural Development Programs (RDPs). This was a descriptive-correlation and a causal-comparative survey study. The population of this study consisted of 5746 farmers and by a stratified proportional random sampling technique, 396 farmers were chosen as sample of the study. To measure structural and cognitive components of social capital variables, a self designed questionnaire was developed to gather needed data. Content validity of the instrument was established by a panel of experts. The finding indicated that, there was a statistically significant difference between adopters and non-adopters in regards to components of social capitals. The result of logistic regression showed that "exchange of information" with peoples or institution, "institutional trust", "social participation", and "formal relations network" were identified as the most discriminative factors ( $73 \%$ of population), affecting adoptions. Therefore, these social capital variables could act as important predicting factors determining adoption and utilization of RDPs programs.
\end{abstract}

Key words: Social Capital, Cognitive, Structure, Adoption, Social Solidarity, Social Trust, Collective Action, Participation, Institutional trust, \& Rural Development.

\section{INTRODUCTION}

The term social capital was first utilized by L.J. Hanifan, an educational administrator in the US, who described it as "those tangible assets in people's daily lives" [45, p. 130]. Namely, good will, fellowship, sympathy, and social intercourse among the individuals and families who make up a social unit ${ }^{[45,42,31]}$. Some authors view social capital differently, Jacobs (1961), used it to describe a norm of social responsibility, a corresponding atmosphere of social trust and interconnecting networks of communication ${ }^{[37]}$. Others viewed it as the ability of social capital to generate economic resources ${ }^{[2]}$. Coleman ${ }^{[4]}$, focused on the structure of social relationships, and how they relate to human capital, and Putnam ${ }^{[32]}$, considered Social Capital in terms of cooperative relationships leading to democracy and membership with civic groups [31]. Some authors defined social capital as "features of social organization such as networks, norms and social trust that facilitate cooperation and coordination for mutual benefit" [36, p. 167]. Similarly, some researchers described social capital as the "social fabric or glue", that ties members of a given society to one another and utilizes the norms of trust and reciprocity ${ }^{[6, p .15,11]}$. A relatively, recent published literature ${ }^{[42]}$, provided a point of consensus among these various perspectives by emphasizing on a concept of "networks of quality relations" which operate as a resource to collective action on different scales (individual, communities, and nations).

Social capital can be understood as existing in either structural or cognitive forms. Both forms arise from the mental rather than the material realm, so both are ultimately cognitive. But structural forms are indirectly rather than directly based on mental processes $[40,41]$. Researchers make a valuable distinction between structural and cognitive forms of social capital. The structural form includes networks, roles, rules, precedents ${ }^{[20,41]}$, and the intensity of associational links or activity that relates to what people 'do' [14]. The cognitive form covers norms, values,

Corresponding Author: Hassan Sadighi (Ph.D.), College of Agriculture, Tarbiat Modares University, P.O.Box 336-14115, Tehran, Iran 
attitudes, and beliefs [20,41] or perceptions of support, reciprocity, sharing, trust, and it relates to what people "feel", [14]. The main difference between the two categories is that structural forms of social capital are relatively external and objectified while cognitive forms of social capital are more internal and subjectified ${ }^{[41] .}$

Communities with high levels of social capital are able to act together collectively for achieving diverse common objectives [19]. In addition to the conventional development capitals, such as financial, human, and physical, social capital is now regarded as a key element in analyzing the development potentials of individuals, organizations, communities, and even nation states [3]. Many economists have argued that social capital positively influences economic development [4,5,36]. Higher levels of social capital within a small regional community will have a positive impact on the level of economic development Woodhouse ${ }^{[43] .}$ Therefore, social capital is crucial to the attainment of the goal of sustainable development [32], and by adding to the stock of social capital, the development performance can be improved ${ }^{[19] \text {. }}$

Rural Development Programs (RDPs) in the Caspian See region of Iran includes integrated pest management, land leveling (due to the topographic nature of areas), land development (Soil conservation), new irrigation practices, efficient land utilization (second cropping), low usage of chemical fertilizer and pesticide (Soil protection), natural resource management, marketing, and cooperative formation. The main research interest in this study is to identify how social capital components could affect the adoption of RDPs among farmers in Caspian See region of Iran? Rural development practitioners have for long been aware that adoption and utilizing RDPs vary considerably from one location to another. In this study, Researchers found that that adoption RDPs vary considerably from one Community to another. Now the question is why? Why is there a high adoption and utilization of RDPs in community $\mathrm{A}$, and not in community B? In providing logical reasoning for such variations, researchers suggested cooperation, and active participation of farmers within their community could be the main responsible factors for such differences. Another possible reason could be on the communities' social capital levels ${ }^{[19] .}$ Putnam's finding specifically states "social capitals" as main variables that enable people to act in cooperation with one another for achieving mutual benefits ${ }^{[32,33,36]}$. Some studies suggested that communities with high levels of social capital are better able to organize and mobilize itself effectively for collective actions. This is due to the high levels of social trust, density of social networks, and well-established norms of mutuality within the community ${ }^{[16]}$. Social capital promotes trust and cooperation among agents, which in turn increases socially efficient collective action [23]. Studies have shown that where social capital indicators are evident, local people are more likely to be motivated to participate with genuine commitment to collaborating with institutional actors for initiatives that lead to sustainable changes in agriculture and resource management ${ }^{[22]}$. These Collaborations provide access to a great range of external resources through extended external networks [17]. The main purpose of this study was to measure social capital (consisting of structural and cognitive) in the activities of mainly rice producing farmers in the Caspian See region of Iran. The secondary purpose was to determine the influence of farmers' social capital on adoption of RDPs. The more specific objectives included: 1) To determine professional and personal characteristics of farmers; 2) To compare adopters and non- adopters of RDPs in regard to their social capitals; and 3) To identify the major components of social capitals responsible for discriminating adopters from non- adopters.

\section{MATERIALS AND METHODS}

Some researchers utilized both quantitative and qualitative methods in their attempts to measure social capital [11]. In this study only quantitative techniques were used to gather and analyze data. This was a descriptive-correlation and a causal-comparative survey study. The population of this study consisted of 5746 farmers and by a stratified proportional random sampling technique, 396 farmers were chosen as sample of the study and were divided into two groups (Adopters of RDPs=184; \& Non-Adopters=212) based on their adoption score of the components of rural development programs (explained in the introduction section). Sample size was obtained and supported by studies of Krejcie and Morgan ${ }^{[18],}$ which offers a table for determining sample size for a given population. Five agricultural extension information and service centers in the study region provided the researchers with the list of farmers which formed the research population for the study. To measure structural and cognitive components of social capital variables, numerous literatures were reviewed for theoretical principles, and a self designed questionnaire was developed to gather needed data for the study. Content validity of the instrument was established by a panel of experts in the area of social sciences, and agricultural 
extension sciences. A pilot test was conducted and data were used to compute the reliability of the instrument. A Cronbach's Alpha reliability coefficients of 0.88 , 0.92 and 0.91 were obtained respectively for "social trust", "social solidarity", and "exchange of information" variables measured in this study. These variables are considered to be cognitive components of social capitals. Similarly, a Cronbach's Alpha reliability coefficients of 0.95 and 0.76 were obtained respectively for "social participation and collective action" and "relations network" variables which considered to be the structured components of the social capitals. A self designed questionnaire was used to gather data for the study. In designing the questionnaire, theoretical concepts, and perspectives on components of social capitals, and how to measure them were taken into consideration. The questionnaire consisted of four parts: part one related to information about professional and personal characteristics of farmers (such as gender, age, education level, experience in agriculture, total land area, cultivated land, main crop production, land ownership, distance from farm to agricultural extension and services centers and etc); part two and three of the instrument were designed to gather data relating to cognitive and structural components of the social capitals respectively; and part gathered data to measure the level of RDPs adoptions among farmers (which consisted of six yes/no questions). In part two and part three, all items in the questioner were based on a fivepoint Likert type scale with responses ranging from zero (not at all) to 4 (very high).

\section{RESULTS AND DISCUSSION}

Respondents Characteristics: The findings showed that $73.5 \%$ of the respondents had an average age of more than 40 years (mean=47.78; \& Std. Dev=12.37), $91.7 \%$ were male, and $80.6 \%$ of farmers in this study were rice producers. The descriptive information indicated that $63.4 \%$ of farmers were either illiterate or had a few years of elementary education. Farmers' professional farming experience ranged from 4 to 57 years $(M=27.8, S D=13.12)$. The mean of land owned by farmers was 0.88 hectare. The average size of cultivated land holding was 0.74 hectare. The average distance from the farm to agricultural extension information service centers was $4.3 \mathrm{~km} .212$ farmers (46.56\%) did not adopt RDPs, where as 184 (53.54\%) of the respondents adopted RDPs in their professional activities. More detail information is presented in table1. The professional characteristics of the respondents found in this study are considered a typical of farmers in the geographic region of the study. Many national agricultural researchers believe those typical farmers' characteristics in this region, particularly; their education levels; and their being small and subsistence farmers may be the main reason responsible for their non-adopting behavior of the RDPs.

Researchers suggests that by improving "social capital" variable in farming population, their condition could be enhanced in respect to adoption of RDPs. Based on Putnam's studies ${ }^{[32,33,36]}$, social capital could have a positive effects by creating, developing and facilitating cooperation, collaboration and collective action among peoples.

Social Capital: The descriptive findings showed that the values of social capital components among adopters were higher than non-adopters of RDPs. Table 2 shows that $65.8 \%$ of the adopters had a moderate level of social capital, where as $25.5 \%$ of non-adopters showed a moderate level of social capital which is consistent with the recent published literature. Various research studies have shown that a well established social capital in a community is an important factor in building and maintaining collective action which is fundamental to long-term adoption of RDPs [1,21,28,29,30,39,44]. Assessments of some success stories in Philippine suggest that collective action is needed to have a sustained adoption of RDPs in a community $[9,12,13,25]$. Cramb ${ }^{[8]}$ concluded that the rate of adoption of soil conservation was considerably enhanced where appropriate forms of social capital are either already in place or are being developed. In addition, membership in a local land care group created a valuable stock of social capital, with significant benefits for long-term natural resource management.

Comparison of Adopters and Non-Adopters: An independent-samples t-test was conducted to evaluate the differences between adopters and non-adopters of RDPs. As shown in table 3, there was a statistically significant differences between adopters and nonadopters in regards to social trust, social solidarity and exchange of information (cognitive social capital components) and social participation and collective action, and relations network (structural social capital components). The findings indicate that adopters had higher levels of social capital than non-adopters to organize and mobilize effectively for participation and collective action for adoption RDPs. This finding is consistent with the results various published literature [16,23,15,24]. The results implied that high levels of social capital components within adopters' community act as motivating factors to increase their social participation and collective action activities. This confirms the results found in Kroma and Flora ${ }^{[22]}$, Kilpatrick ${ }^{[17]}$, and Cramb et al, ${ }^{[9]}$ studies. 
Am. J. Agril. \& Biol. Sci., 2 (1): 15-22, 2007

Table 1: Professional and Personal Characteristics of Farmers

\begin{tabular}{|c|c|c|c|c|}
\hline Variables & Mean & Std.Dev. & Minimum & Maximum \\
\hline Age (year) & 47.78 & 12.367 & 24 & 81 \\
\hline Experience in agricul. (year) & 27.76 & 13.122 & 4 & 57 \\
\hline Household member & 4.8 & 1.694 & 1 & 10 \\
\hline Total land (hector) & 0.875 & .653 & 0.3 & 15 \\
\hline Land holding(hector) & 0.74 & .64 & 0.2 & 15 \\
\hline \multirow{2}{*}{$\begin{array}{l}\text { Distance from farm to Ag. Ex. \& } \\
\text { Service Centers }(\mathrm{km})\end{array}$} & 4.3 & 1.547 & 0.5 & 8 \\
\hline & $\mathrm{f}$ & percentage & $\begin{array}{l}\text { Cumulative } \\
\text { percentage }\end{array}$ & \\
\hline \multicolumn{5}{|l|}{ Gender } \\
\hline Male & 363 & 91.7 & 91.7 & \\
\hline Female & 33 & 8.3 & 100 & \\
\hline Total & 396 & 100 & & \\
\hline \multicolumn{5}{|l|}{ Main cultivation } \\
\hline Rice & 341 & 86.1 & 86.1 & \\
\hline Tea & 22 & 5.6 & 91.7 & \\
\hline Citrus fruit & 33 & 8.3 & 100 & \\
\hline Total & 396 & 100 & & \\
\hline \multicolumn{5}{|l|}{ Main occupation } \\
\hline Rice farming & 319 & 80.6 & 80.6 & \\
\hline Tea farming & 22 & 5.6 & 86.1 & \\
\hline Citrus fruit producer & 33 & 8.3 & 94.4 & \\
\hline Animal husbandry & 8 & 2 & 96.4 & \\
\hline Others & 14 & 3.5 & 100 & \\
\hline Total & 396 & 100 & & \\
\hline \multicolumn{5}{|l|}{ Land ownership } \\
\hline Owner & 291 & 73.5 & 73.5 & \\
\hline Renter/contractor & 4 & 1 & 74.5 & \\
\hline Granted & 7 & 1.8 & 76.3 & \\
\hline others & 94 & 23.7 & 100 & \\
\hline Total & 396 & 100 & & \\
\hline
\end{tabular}

Major Variables Influencing Adoption: A forward stepwise logistic regression analysis technique was employed to identify the most important discriminative social capital factors affecting adopters and nonadopters of RDPs. The statistically significant dependent variables in (an independent) t-test were used as independent variables in logistic regression analysis (table 3). The findings indicated that the logistic regression stopped on the fourth step, and variables such as "exchange of information" with peoples or institution, "institutional trust", "social participation and collective action", and "formal relations network" were found as the most important discriminative social capital components. Table 4 shows the detail analysis of the logistic regression test. These factors made a valuable distinction between $73 \%$ of population. This is consistent with the results found in various related studies ${ }^{[8,9,13,25,12]}$. The variability of Chi-square showed high magnitude and effect of discriminative variables (social capital components) on adoption of RDPs (table 4). 
Am. J. Agril. \& Biol. Sci., 2 (1): 15-22, 2007

Table 2: Social Capital Status Comparing Adopters and Non-Adopters

\begin{tabular}{|c|c|c|c|c|c|c|c|}
\hline \multirow[b]{2}{*}{ Variables } & & \multicolumn{3}{|c|}{ Adopters } & \multicolumn{3}{|c|}{ Non-adopters } \\
\hline & & $\mathrm{f}$ & Percentage & $\begin{array}{l}\text { Cumulative } \\
\text { percentage }\end{array}$ & $\mathrm{f}$ & Percentage & $\begin{array}{l}\text { Cumulative } \\
\text { percentage }\end{array}$ \\
\hline \multirow[t]{3}{*}{ Social trust } & W & 34 & 18.5 & 18.5 & 134 & 63.2 & 63.2 \\
\hline & M & 115 & 62.5 & 81 & 56 & 26.4 & 89.6 \\
\hline & $\mathrm{G}$ & 35 & 19 & 100 & 22 & 10.4 & 100 \\
\hline \multirow[t]{3}{*}{ Social solidarity } & W & 44 & 23.9 & 23.9 & 137 & 64.6 & 64.5 \\
\hline & $\mathrm{M}$ & 88 & 47.8 & 71.7 & 37 & 17.5 & 82.1 \\
\hline & $\mathrm{G}$ & 52 & 28.3 & 100 & 38 & 17.9 & 100 \\
\hline \multirow[t]{3}{*}{ Exchange of information } & W & 18 & 9.8 & 9.8 & 86 & 40.6 & 40.6 \\
\hline & $\mathrm{M}$ & 102 & 55.4 & 65.2 & 83 & 39.2 & 79.8 \\
\hline & G & 64 & 34.8 & 100 & 43 & 20.3 & 100 \\
\hline \multirow[t]{3}{*}{ Cognitive total } & $\mathrm{W}$ & 44 & 23.9 & 23.9 & 129 & 60.8 & 60.8 \\
\hline & $\mathrm{M}$ & 83 & 45.1 & 69 & 34 & 16 & 76.9 \\
\hline & $\mathrm{G}$ & 57 & 31 & 100 & 49 & 23.1 & 100 \\
\hline \multirow{3}{*}{$\begin{array}{l}\text { Participation \& } \\
\text { collective action }\end{array}$} & W & 29 & 15.8 & 15.8 & 133 & 62.7 & 62.7 \\
\hline & M & 73 & 39.7 & 55.4 & 35 & 16.5 & 79.2 \\
\hline & G & 82 & 44.6 & 100 & 44 & 20.8 & 100 \\
\hline \multirow[t]{3}{*}{ Relations network } & $\mathrm{W}$ & 29 & 15.8 & 15.8 & 149 & 70.3 & 70.3 \\
\hline & $\mathrm{M}$ & 89 & 48.4 & 64.1 & 11 & 5.2 & 75.5 \\
\hline & G & 66 & 35.9 & 100 & 52 & 24.5 & 100 \\
\hline \multirow{3}{*}{ Structural total } & W & 52 & 28.3 & 28.30 & 141 & 66.5 & 66.5 \\
\hline & $\mathrm{M}$ & 66 & 35.9 & 64.1 & 38 & 17.9 & 84.4 \\
\hline & $\mathrm{G}$ & 66 & 35.9 & 100 & 33 & 15.6 & 100 \\
\hline \multirow[t]{3}{*}{ Social capital total } & $\mathrm{W}$ & 26 & 14.1 & 14.1 & 116 & 54.7 & \\
\hline & $\mathrm{M}$ & 121 & 65.8 & 79.9 & 54 & 25.5 & \\
\hline & $\mathrm{G}$ & 37 & 20.1 & 100 & 42 & 19.8 & \\
\hline Total & & 184 & 100 & & 212 & 100 & \\
\hline
\end{tabular}

Table 3: Comparison of Adopters and Non-Adopters in respects to Social Capital

\begin{tabular}{|c|c|c|c|c|c|c|}
\hline \multirow{3}{*}{ Variables } & \multirow{2}{*}{\multicolumn{2}{|c|}{ Adopters }} & \multirow{2}{*}{\multicolumn{2}{|c|}{ Non-adopters }} & \multirow{3}{*}{$\mathrm{t}$} & \multirow[t]{3}{*}{$P$ value } \\
\hline & & & & & & \\
\hline & Mean & Std.Dev & Mean & Std.Dev & & \\
\hline Interpersonal trust & 9.48 & .092 & 9.44 & .097 & -.297 & .76 \\
\hline Generalized trust & 5.89 & 2.626 & 9.54 & 2.351 & -5.411 & .000 \\
\hline Institutional trust & 12.02 & 4.374 & 9.08 & 3.441 & -7.358 & .000 \\
\hline Social trust & 27.39 & 7.152 & 23.06 & 5.607 & -6.639 & .000 \\
\hline Social interaction & 10.48 & 3.209 & 9.14 & 3.458 & -3.997 & .000 \\
\hline Attitude to social cooperation & 7.84 & 2.854 & 7.02 & 2.742 & -2.888 & .004 \\
\hline Social conflict & 8.26 & 2.954 & 7.23 & 2.785 & -3.550 & .000 \\
\hline Social solidarity & 26.158 & 8.656 & 23.39 & 8.696 & -3.648 & .000 \\
\hline Exchange of information (internal) & 13.32 & 2.423 & 13.15 & 2.463 & -0.708 & .479 \\
\hline Exchange of information (external) & 8.34 & 2.779 & 5.82 & 2.362 & -9.649 & .000 \\
\hline Exchange of information & 21.66 & 4.441 & 18.97 & 3.907 & -6.369 & .000 \\
\hline Cognitive social capital (total) & 75.63 & 16.368 & 65.41 & 14.102 & -6.605 & .000 \\
\hline Social participation and collective action & 19.12 & 7.098 & 15.87 & 6.226 & -4.812 & .000 \\
\hline Informal relationships & 6.72 & 1.162 & 6.64 & 1.046 & -.726 & .468 \\
\hline Formal relationships & 6.79 & 2.308 & 5.22 & 1.853 & -7.372 & .000 \\
\hline Relations network & 13.51 & 2.953 & 11.86 & 2.480 & -5.958 & .000 \\
\hline Structural social capital & 32.63 & 8.515 & 27.73 & 7.221 & -6.123 & .000 \\
\hline Social capital(total) & 108.26 & 24.140 & 93.14 & 20.349 & -6.681 & .000 \\
\hline
\end{tabular}


Am. J. Agril. \& Biol. Sci., 2 (1): 15-22, 2007

Table 4: Discriminative Social Capital Variables Affecting Adoption.

\begin{tabular}{clcccc}
\hline Step & Variable & Correct Class \% & Chi-square & df & P-value \\
\hline 1 & Exchange of information (external) & 65.7 & 85.607 & 1 & 0.000 \\
2 & Institutional trust & 69.4 & 106.782 & 2 & 0.000 \\
3 & Social participation and collective & 70.7 & 116.402 & 3 & 0.000 \\
& action & 73 & 126.426 & 4 & 0.000 \\
\hline
\end{tabular}

Table 5: Variables in Logistic Regression Analysis

\begin{tabular}{lccccc}
\hline Variable & B(Beta) & SE & df & P-value & EXP(B) \\
\hline Exchange of information, external & 0.336 & 0.052 & 1 & 0.000 & 1.399 \\
(X) & 0.221 & 0.049 & 1 & 0.000 & 1.248 \\
Institutional trust $\left(\mathrm{X}_{2}\right)$ & 0.431 & 0.103 & 1 & 0.000 & .650 \\
Social participation and collective & 0.129 & 0.042 & 1 & 0.002 & 1.138 \\
action $\left(\mathrm{X}_{3}\right)$ & -3.807 & 0.494 & 1 & 0.000 & 0.022 \\
formal relations network $\left(\mathrm{X}_{4}\right)$ & & & & \\
Constant &
\end{tabular}

For predicating probability of framer's decision to adopt RDPs, the logit of $\mathrm{f}(\mathrm{x})$ function is calculated and could be inferred to the population of this study (Table 5 ). Based on statistically significant variables in the logistics regression analysis, and constant values, the logistic regression equation could be derived as follows:

$\mathrm{F}(\mathrm{x})=-3.807+0.336\left(\mathrm{X}_{1}\right)+0.221\left(\mathrm{X}_{2}\right)+0.431\left(\mathrm{X}_{3}\right)+$ $0.129\left(\mathrm{X}_{4}\right)$. The magnetite of $\mathrm{f}(\mathrm{x})$ could be predicted by determining the value of each major variable in this equation. The positive values of beta in this equation indicate that by increasing the value of these four variables, the probability of farmers deciding to adopt RDPs will increase.

\section{CONCLUSIONS}

Based on the finding of this study, the following conclusions were drawn.

1. The descriptive characteristics of the respondents found in this study were indeed inevitable findings. The majority of farmers in this study was subsistent farmers, non-adopters of RDPs, and had low literacy. These professional characteristics are considered to be typical and representative of the population. Based on theoretical studies, in situation that typical characteristics are not easily changeable in short time, it is advised to capitalize time and efforts in changing the parameter of personal and collective aspects of social capitals in order to enhance farmers' social and economical condition.
2. Adopters had higher levels of: social capital (cognitive, and structure); higher appreciations for effective participation; and collective action process than non-adopters, which is consistent with other research studies found in the literature.

3. Similarly, the components of cognitive social capital (such as social trust, social solidarity, exchange of information), and components of structural social capital (such as social participation and collective actions, and social networks) were higher in adopters of RDPs than non-adopters of the programs.

4. As various aspects of social capitals increases in individuals or community, the probability of deciding to adopt RDPs increases, therefore it could be stated that social capital is a determinant factor in adoption.

5. Social capital was an important factor in building and maintaining effective participation, collective action, and increasing motivation which was fundamental to adoption of RD programs.

6. The results of logistic regression analysis identified four variables, namely, "exchange of information" with peoples or institution, "institutional trust", "social participation and collective action", and "formal relations network" as the most important discriminating variables affecting adoption of rural development programs (statistically significant relations were found between them and adoption of rural development programs). These factors made a valuable distinction among $73 \%$ of the population. 


\section{REFERENCES}

1. Agrawal, A., and C.C., Gibson, 1999. Enchantment and disenchantment: The role of community in natural resource conservation. World Development, 27(4): 629-649.

2. Bourdieu, P., 1986. The forms of capital. In: J.G., Richardson, (Ed.), Handbook of theory and research for the sociology of education. Greenwood, New York, pp: 241-258.

3. Brown, T.F, 1998. Theoretical perspectives on social capital. [On-Line]. Available at: Http:jhunix.edu/-tombrown/Econsoc/soccap.html

4. Coleman, J., 1988. Social capital in the creation of human capital. American Journal of Sociology, 94: 95-120.

5. Coleman, J.S., 1990. Foundations of Social Theory. Harvard University Press, Cambridge, MA.

6. Cox, E., 1995. A Truly Civil Society. ABC Books, Sydney, Australia.

7. Cox, E., 1997. Building social capital. Health Promotion Matters, 4: 1-4.

8. Cramb. R.A., 2004. Social capital and soil conservation: Evidence from the Philippines, Contributed Paper, 48th Annual Conference, Australian Agricultural and Resource Economics Society, Melbourne.

9. Cramb, R.A., J.N.M., Garcia, R.V., Gerrits, and G.C. Saguiguit, 2000. Conservation farming projects in the Philippine uplands: Rhetoric and reality. World Development, 28:911- 928.

10. Davis, J.A., 1971. Elementary survey analysis. Englewood, Prentice Hall, NJ.

11. Field, J., 2003. Social capital. Routledge, London.

12. Fujisaka, S., 1993. A case of farmer adaptation and adoption of contour hedgerows for soil conservation. Experimental Agriculture. 29: 97-105.

13. Garcia, J.N.M., R.V., Gerrits, and R.A., Cramb, 2002. Adoption and maintenance of contour bunds and hedgerows in a dynamic environment: Experience in the Philippine uplands. Mountain Research and Development, 22: 10-13.

14. Harpham, T., E. Grant, and E. Thomas, 2002. Measuring social capital within health surveys: Key Issues. Health Policy and Planning, 17: 106111.

15. Harris, J., and P. Renzo, 1997. Policy arena 'missing link' or analytically missing? The concept of social capital-an introductory bibliographic essay. Journal of International Development, 9(7): 919-937.
16. Kavanaugh, A. L, D.D. Reese, J.M. Carroll, and M.B. Rosson, (2005). Weak ties in networked Communities. The Information Society. 21: 119131.

17. Kilpatrick, S., 2004. Education and training institutions: Building social capital for regional development. Research and Learning in Regional Australia. University of Tasmania.

18. Krejcie, R.V., and D.W. Morgan, 1970. Determining Sample Size for Research Activities. Educational and psychological measurement, 30: 608.

19. Krishna, A., 2003. Understanding, Measuring and Utilizing Social Capital: Clarifying Concepts and Presenting a Field Application from India. Capri Working Paper, 28.

20. Krishna, A., and E. Shrader, 1999. Social Capital Assessment Tool, Paper prepared for the Conference on Social Capital and Poverty Reduction. The World Bank, Washington, DC.

21. Krishna, A., and N. Uphoff, 1998. Mapping and measuring social capital: A conceptual and empirical study of collective action for conserving and developing watersheds in Rajasthan, India. Cornell University Mimeo. Ithaca, NY.

22. Kroma, M., and C. Flora, 2001. An assessment of SARE-funded projects in the North Central Region. American Journal of Alternative Agriculture, 16(2): $18-31$.

23. La Porta, R., F. Lopez-de-Silanes, A. Shleifer, and R.W. Vishny, 1997. Trust in large organizations. American Economic, 87: 333-338.

24. Lyon, F., 2000. Trust, networks and norms: The creation of social capital in agricultural economics in Ghana. World Development, 28(4): 663-681.

25. Mercado, A.R., M. Patindol, and D.P. Garrity, 2001. The Landcare experience in the

26. Philippines: technical and institutional innovations for conservation farming. Development in Practice, 11: 495-508.

27. Portes, A., 1998. Social capital: its origins and applications in modern sociology. Annual Review of Sociology, 24: 1-24.

28. Pretty, J., 2003. Social capital and the collective management. Science, 302: 1912-1915.

29. Pretty, J., and D. Smith, 2004. Social capital in biodiversity conservation and management. Conservation Biology, 18(3): 631-638.

30. Pretty, J. and H. Ward, 2001. Social capital and the environment. World Development, 29(2): 209227. 
31. Pooley, J. A., L, Cohen, and L.T. Pike, 2005. Can sense of community inform social capital? The Social Science Journal, 42: 71-79.

32. Putnam, R., 1993. The prosperous community: Social capital and public life. The American Prospect, 13: 35-42.

33. Putnam, R. (1995). Bowling alone: America's declining social capital. Journal of Democracy. 6:65-78.

34. Putnam, R., 1996. The strange disappearance of civic America. Policy, 3-15.

35. Putnam, R., 2000. Bowling Alone: the collapse and revival of American community. Simon and Schuster, New York.

36. Putnam, R., R. Leonardi, and R.Y. Nanetti, 1993. Making Democracy Work. Princeton University Press, Princeton.

37. Roseland, M., 2000. Sustainable community development: Integrating Environmental, economic, and social objectives. Progress in Planning, 54: 73-132.

38. Schuller, T., S. Baron, and J. Field, 2000. Social capital: A review and critique. In: S. Baron, J. Filed, and T. Schuller, (Eds.), Social Capital: Critical Perspectives. Oxford University Press, Oxford, pp: 1-38.

39. Steins, N. A., and V.M. Edwards, 1999. Platforms for collective action in multiple-use common pool resources. Agriculture and Human Values, 16: 241-255.
40. Uphoff, N., 1996. Learning from Gal Oya: Possibilities for participatory development and post-Newtonian social science. Intermediate Technology Publications, London.

41. Uphoff, N., and C.M. Wijayaranta, 2000. Demonstrated Benefits from Social Capital: The Productivity of Farmer Organizations in Gal Oya, Sri Lanka. World Development, 28 (11): 18751890.

42. Winter, I. (Ed.), 2000. Social capital and public policy. Institute of Family Studies. Melbourne, Australia,

43. Woodhouse, A., 2006. Social capital and economic development in regional Australia: A case study. Journal of Rural Studies, 22: 83-94.

44. Woolcock, M., 1998. Social Capital and Economic Development: Toward a Theoretical Synthesis and Policy Framework. Theory and Society, 27(2): 151-208.

45. Woolcock, M., and D. Narayan D., 2000. Social capital: Implications for development theory, research, and policy. World Bank Research Observer, 15(2): 225-49. 